\title{
State Disinvestment in Higher Education: The Impact on Public Research Universities' Patent Applications
}

\author{
Bo Zhao
}

\begin{abstract}
:
While state appropriations are the largest revenue source of the U.S. public university systems, they have declined significantly over the past several decades. Surprisingly, there is little empirical work on the effect of state appropriation cuts on the research productivity of public universities. Helping fill that gap, this paper is the first to examine the role that state appropriations play in public universities' patent production. The results suggest that state appropriation cuts have a negative impact on the number of approved patent applications from public research universities. Lower state appropriations are shown to lead to a reduction in research expenditures, especially wages and salaries paid to research staff.
\end{abstract}

\section{JEL Classifications: H75, H77, I23}

Keywords: state appropriations, state funding cuts, higher education, public universities, patent applications

Bo Zhao is a senior economist at the New England Public Policy Center in the Federal Reserve Bank of Boston Research Department. His e-mail address is bo.zhao@bos.frb.org.

The author would like to thank Margaret E. Blume-Kohout, Katharine Bradbury, Osborne Jackson, Leslie E. Papke, Robert Triest, and participants at the National Tax Association Annual Conference, the Association for Public Policy Analysis and Management Annual Fall Research Conference, and the New England Public Policy Center Brown Bag Seminar for helpful comments. Calvin Kuo provided research assistance.

This paper presents preliminary analysis and results intended to stimulate discussion and critical comment. The views expressed herein are those of the author and do not indicate concurrence by the Federal Reserve Bank of Boston, the principals of the Board of Governors, or the Federal Reserve System.

This paper, which may be revised, is available on the website of the Federal Reserve Bank of Boston at http://www.bostonfed.org/economic/wp/index.htm. 


\section{Introduction}

In addition to educating students, public research universities pursue a core mission of producing high-quality research (Castellanos 2015). ${ }^{1}$ Their research activities are important and relevant for public policies in part because they have positive spillovers that increase social benefits. New academic research often provides a foundation for innovations in pharmaceuticals, information technologies, and other high-tech industries (Mansfield 1995). The research activity can especially benefit the local economy and industries, because the externality is often concentrated in a small geographic area near the school (Jaffe 1989; Bania, Eberts, and Fogarty 1993; Mansfield and Lee 1996; Anselin, Varga, and Acs 1997; Adams 2002; Zheng and Slaper 2016). Therefore, many people argue that the research capacity of public universities affects the economic growth and competitiveness of their host communities and states (Castellanos 2015; Conroy and Shannon 2015).

States play a critical role in financing public universities in the United States; however, that role has been diminishing over the past several decades (Kane, Orszag, and Gunter 2003; Kane, Orszag, and Apostolov 2005; Tandberg 2010; Goodman and Henriques 2015). Figure 1 shows that state appropriations, as the largest revenue source in aggregate, accounted for about 34 percent of U.S. public universities' total revenue in 1993. The share dropped to less than 18 percent in 2014. Furthermore, Long (2016) shows that cuts in state appropriations for higher education have affected all types of public institutions, including public research universities.

Many scholars and the popular press call this phenomenon "state disinvestment in higher education" (Delisle 2017). It is particularly concerning given that the demand for higher education

\footnotetext{
${ }^{1}$ The Carnegie Classification of Institutions of Higher Learning defines a public research university as a public institution that awards at least 20 research/scholarship doctoral degrees a year.
} 
has been trending up, not down, in recent decades. For example, the immediate-college-enrollment rate for high school graduates rose from 63 percent in 2000 to 69 percent in $2015 .^{2}$

There are at least two reasons why state funding of higher education is eroding. First, states often resort to cutting higher education funding to help close budget gaps (Povich 2015). In the words of Serna and Harris (2014), public higher education has become the "balance wheel" of state budgets. This pattern was particularly prominent during the two recent recessions, when states faced severe and unprecedented fiscal crises (Mitchell and Leachman 2015; Mitchell, Leachman, and Masterson 2016). For instance, every state except Alaska and North Dakota cut higher education spending during the 2007-2009 Great Recession (Mitchell and Leachman 2015). The second reason is that ever-growing Medicaid spending has crowded out state spending on higher education (Kane, Orszag, and Gunter 2003; Okunade 2004; and Kane, Orszag, and Apostolov 2005). Since fiscal year 2009, Medicaid has surpassed elementary and secondary education as the largest state spending category. About 27 percent of state expenditures in the United States were devoted to Medicaid in fiscal year 2015 (NASBO 2015).

Many policymakers, practitioners, and researchers, as well as the public, are concerned about the negative implications of declining state support for public higher education (Conroy and Shannon 2015). Against this backdrop, this paper examines the effect of changes in state appropriations on public research universities' patent-research productivity. It investigates whether (and how) the effect varies by university type and over time. In addition, this paper explores the channels through which state appropriations may affect public research universities' patent research.

\footnotetext{
${ }^{2}$ See https://nces.ed.gov/programs/coe/indicator_cpa.asp.
} 
This paper builds on three strands of the related literature. The first strand studies how state funding affects public universities' education function. For example, Koshal and Koshal (2000), Lowry (2001), the National Center for Education Statistics (NCES 2001), Rizzo and Ehrenberg (2004), Kim and Ko (2015), Goodman and Henriques (2015), and Webber (2017) suggest that state funding cuts result in tuition and fee increases at public universities. Jaquette and Curs (2015) reveal a negative relationship between state appropriations and nonresident freshman enrollment, which implies that public universities respond to state funding cuts by attracting more high-paying out-of-state students. The research by Goodman and Henriques (2015) indicates that state funding cuts may also lead to a shift in student enrollment from public institutions to private for-profit institutions; as a result, students have to increase borrowing to pay for the higher tuition and fees at the private for-profit institutions. In addition, Zhang (2009) finds a positive relationship between state funding and graduation rates at public four-year institutions. This result implies that state funding cuts could have a negative effect on college graduation rates.

In comparison, there has been surprisingly little empirical work on the impact of state appropriations on public universities' research output in the United States. To the best of my knowledge, Husted and Kenny (2015) have written the only paper on this subject. The authors suggest that a reduction in state appropriations results in public university scholars' publishing fewer pages in top-50 economics journals.

The third strand of the related literature focuses on the impact of earmarked federal research and development $(R \& D)$ spending and grants on research production, which is measured mostly by the number of papers published in academic journals. For example, Payne (2002) suggests that U.S. Congressional earmarked R\&D funding increases the number of articles published by university researchers, but it decreases the number of citations per article. Payne and Siow (2003) 
show that an increase in U.S. federal research funding results in more published papers and more patents linked to universities. Arora and Gambardella (2005) find that National Science Foundation (NSF) grants have a modest effect on the number of published articles by grant recipients in the field of economics. Jacob and Lefgren (2011a and 2011b) show that a National Institutes of Health (NIH) Research Project Grant Program (R01) grant increases the recipient's number of published articles over the ensuing five years by an average of 7 percent, and an NIH postdoctoral training grant increases it by an average of 20 percent. In addition, Gush, Jaffe, Larsen, and Laws (2017) and Popp (2016) show that government R\&D funding in New Zealand and other countries leads to more published articles in journals.

To the best of my knowledge, this paper is the first to examine the effect of state appropriations on public research universities' patent applications in the United States. The analysis in this paper could help policymakers and practitioners better understand the broad implications of cuts to state funding for higher education.

\section{Conceptual Framework}

Following the literature, this paper assumes that a public research university aims to maximize its prestige, subject to a balanced-budget constraint (for example, Garvin 1980, Ehrenberg and Sherman 1984, Ehrenberg 2000, and Rizzo and Ehrenberg 2004). ${ }^{3}$ That is,

$$
\begin{gathered}
\operatorname{Max} U\left(\frac{q_{1}}{N}, \frac{q_{2}}{N}, \frac{q_{3}}{N}\right) \\
\text { s.t. } \frac{E}{N}=\frac{R_{1}}{N}+\frac{R_{2}}{N}+\frac{R_{3}}{N} .(1)
\end{gathered}
$$

Here $U$ is university prestige, which is assumed to depend on the university's educational output $\left(\frac{q_{1}}{N}\right)$, research output $\left(\frac{q_{2}}{N}\right)$, and public service $\left(\frac{q_{3}}{N}\right)$, while $N$ is the number of full-time-equivalent

\footnotetext{
${ }^{3}$ For simplicity, this paper uses a static model that ignores schools' saving and borrowing behavior.
} 
(FTE) students. $\frac{E}{N}$ is the amount of total expenditures per FTE student. $\frac{R_{1}}{N}$ is tuition and fees, net of institutional grants awarded to students, per FTE student. $\frac{R_{2}}{N}$ is state appropriations per FTE student. $\frac{R_{3}}{N}$ is other revenues per FTE student, including federal appropriations, local appropriations, federal grants and contracts, investment return, and private gifts, grants, and contracts. ${ }^{5}$ These other revenues tend to be much smaller than net tuition and fees and state appropriations, and often they are earmarked for special purposes.

Research expenditures are ultimately funded by the three revenue sources. That is,

$$
\frac{E_{2}}{N}=\rho_{1} \frac{R_{1}}{N}+\rho_{2} \frac{R_{2}}{N}+\rho_{3} \frac{R_{3}}{N},(2)
$$

where $\rho_{1}, \rho_{2}$, and $\rho_{3}$ represent how much money is allocated to research expenditures $E_{2}$ for each $\$ 1$ increase in net tuition and fees, state appropriations, and other revenues, respectively. In theory, $\rho_{1}, \rho_{2}$, and $\rho_{3}$ could be the same, because money is fungible. Alternatively, they could be different, because some revenues are earmarked for research or non-research purposes.

Research productivity depends on research expenditures, which are used to purchase inputs and intermediate goods and services for research activities (Whalley and Hicks 2014). Groot, McMahon, and Volkwein (1991) and Husted and Kenny (2015) also find evidence of considerable economies of scale in university research production. In empirical research, such economies of scale are often approximated by the size of the student enrollment. Therefore, a simple researchproduction function can be described as follows:

\footnotetext{
${ }^{4}$ As previous studies point out, it is important to scale school finances and outputs by the size of the school (often approximated by the number of FTE students) to make them more comparable across universities and over time.

${ }^{5}$ Federal grants and contracts (less Pell Grants if they are reported as part of federal grants by universities) are awarded to universities by federal governmental agencies for contracted training programs, research, or public-service activities. Private gifts, grants, and contracts are revenues received from private donors or from private contracts for specific goods and services provided to the funder.
} 


$$
\frac{q_{2}}{N}=f\left(\frac{E_{2}}{N}, N\right)
$$

Substituting $\frac{E_{2}}{N}$ with equation (2) results in

$$
\frac{q_{2}}{N}=f\left(\frac{R_{1}}{N}, \frac{R_{2}}{N}, \frac{R_{3}}{N}, N\right)
$$

When everything else is held constant, state appropriations $\frac{R_{2}}{N}$ are expected to have a positive effect on research productivity $\frac{q_{2}}{N}$.

\section{Empirical Methodology}

This paper estimates a reduced form of equation (4) using the following fixed-effects panel data model as the baseline specification: ${ }^{6}$

$$
\left(\frac{q_{2}}{N}\right)_{i t}=\alpha+\beta_{1}\left(\frac{R_{1}}{N}\right)_{i t}+\beta_{2}\left(\frac{R_{2}}{N}\right)_{i t}+\beta_{3}\left(\frac{R_{3}}{N}\right)_{i t}+\gamma N_{i t}+I_{i}+T_{t}+v_{i t},(5)
$$

where $i$ is an index for institution, and $t$ is an index for year. All financial variables are converted into 2012 dollars.

This paper measures research output $\left(q_{2}\right)_{i t}$ as the number of patent applications filed by institution $i$ in year $t$ and then eventually approved by the U.S. Patent and Trademark Office (USPTO) in year $t$ or later. Due to data limitations, I do not observe the number of rejected patent applications at the institution level in each year. The USPTO reports that about 35 percent of all patent filings are never approved. ${ }^{7}$ Since granted patents must pass a certain quality threshold predetermined by the USPTO, the number of approved patent applications can be loosely considered a quality-adjusted measure of research output.

\footnotetext{
${ }^{6}$ This paper does not use $\log \left(\left(\frac{q_{2}}{N}\right)_{i t}\right)$ as a dependent variable, because some institutions have zero approved patent applications in parts of the sample period.

${ }^{7}$ See https://www.uspto.gov/web/offices/ac/ido/oeip/taf/univ/org_fi/explan.htm.
} 
This paper measures granted patents distributed by year of patent application, not by year of patent issuance. The USPTO emphasizes that "the date an application was filed more accurately reflects when the technology was developed. Additionally, fluctuations in patent data distributed by application date are much more likely to reflect changes in technological activity, since such fluctuations would for the most part be immune to changes in U.S. Patent and Trademark Office (USPTO) processing such as occurred in years such as 1986 when the USPTO issued fewer patents than would normally have been expected due to a lack of funds to print patents."

On the right-hand side of equation (5), $I$ is institution fixed effects, which capture constant institution-specific factors that may affect a school's research productivity. For example, some universities may have a stronger innovation culture than other universities. Because this paper controls for institution fixed effects, the identification relies on the variation within institutions from one year to the next. By controlling for these fixed effects, this paper reduces the possibility that the results are driven by the unobserved heterogeneity of schools - a shortcoming that some earlier works suffer because they use cross-sectional regressions (for example, Koshal and Koshal 2000, Lowry 2001, Kim and Ko 2015). $T$ is year fixed effects, which capture time-varying macro factors that affect all universities in each given year, such as national economic recessions. Lastly, $v$ is the error term.

This paper considers different estimates of $\beta_{2}$ depending on whether the institution-level state appropriations are treated as endogenous using instrumental variables (IV). The non-IV results are obtained under an assumption that, for several reasons, the likelihood of reverse causality between state appropriations and approved patent applications is relatively low. First, in this paper's sample period of 1987-2003, states were still using a traditional, enrollment-based

\footnotetext{
${ }^{8}$ See https://www.uspto.gov/web/offices/ac/ido/oeip/taf/univ/org_fi/explan.htm.
} 
model to determine the state funding for each public higher education institution, without paying much attention to each institution's patent activities (National Conference of State Legislatures [NCSL] 2015). ${ }^{9}$

Second, due to the state-budget-making process, the amount of state appropriations for higher education is determined much earlier than the filing of patent applications in the corresponding year. Usually in the first half of calendar year $t-1$, state legislatures set the higher education funding for academic year $t$, which generally runs from September in calendar year $t-$ 1 through June in calendar year $t$. For 19 states with biennial budgets, the amount of state appropriations for academic year $t$ could be determined even earlier, in calendar year $t-2$ (Snell 2011). In comparison, the USPTO publishes only the total number of patent applications filed in each full calendar year. Therefore, when a public university files its first patent application in calendar year $t$, it is already six or more months after the state has determined the appropriations for academic year $t$.

Third, because it takes a long time for the USPTO to review and approve a patent application, the total number of approved patent applications filed in year $t$ is not known to the applicant universities and states until several years later. According to the USPTO, the average waiting period between the filing of a patent application and the issuing of that patent (if it is ever

\footnotetext{
${ }^{9}$ Only recently have some states started to incorporate performance indicators into their higher education funding models, in order to introduce more school accountability and to better align higher education funding with state objectives and priorities. These new, "performance-based" funding models are predominantly based on measures of education outcomes, not research outcomes, such as rate of course completion, time to earn degree, transfer rates, the number of degrees awarded, or the number of low-income and minority graduates. Only three states-Arkansas, Mississippi, and Virginia-reportedly include patents as one of the many performance indicators in their funding models, although Arkansas treats patents only as an optional performance measure for its public four-year institutions (NCSL 2015). Furthermore, these three states consider patents awarded in the previous year(s), not patent applications that will be filed in the upcoming year, since such information cannot be available when the states make their budgets. In addition, states that recently adopted the performance-based models use the new models to allocate only a small portion of the total higher education funding, while relying on the old, enrollment-based models to allocate the majority of the state funding. For example, Illinois, Pennsylvania, Indiana, Texas, and Louisiana allocate less than 1 percent, 2.4 percent, 6 percent, 10 percent, and 15 percent, respectively, of their higher education funding through the performance-based models (NCSL 2015).
} 
granted) is 32 months. On December 31, 2012, more than half of the patent applications filed in 2008 were still pending. The USPTO also notes that "a patent's 'pendency' can be quite variable from one patent to another thereby affecting the date of patent grant. Such variation in pendency is determined by many factors, including USPTO workload (which varies between technologies), budget and manpower levels, patent printing schedules, etc." ${ }^{\prime 10}$ Because of this significant and highly uncertain time delay, it is hard to imagine that the total number of patent applications filed by a university in calendar year $t$ and subsequently approved by calendar year $t+n$ would affect the state decision, made in calendar year $t-1$ or $t-2$, on appropriations to this university for academic year $t$.

In addition, the over-time variation in state appropriations is often generated by factors that are plausibly orthogonal to patent production. ${ }^{11}$ For example, economic recessions cause large state revenue shortfalls; states respond by making deep cuts in higher-education funding to help address budget gaps (Mitchell and Leachman 2015; Mitchell, Leachman, and Masterson 2016). Kane, Orszag, and Gunter (2003), Okunade (2004), and Kane, Orszag, and Apostolov (2005) find that state spending on higher education has been crowded out by the rapid growth of Medicaid spending. Koshal and Koshal (2000) suggest that per capita tax revenue and a clear majority of Democrats in a state legislature affect state appropriations for higher education. Similarly, Okunade (2004) shows that Democratic Party control of a state's governorship and legislature and the lagged level of a state's indebtedness are important determinants of state appropriations for higher education. Weerts and Ronca (2006) demonstrate that the political priorities of a state's governor and legislature are a stronger predictor of state appropriations for higher education than

\footnotetext{
${ }^{10}$ See https://www.uspto.gov/web/offices/ac/ido/oeip/taf/univ/org_fi/explan.htm.

${ }^{11}$ Also recall that the decline in state appropriations per FTE student was not caused by less demand for higher education. On the contrary, the immediate-college-enrollment rate for high school graduates increased from 63 percent in 2000 to 69 percent in 2015. See https://nces.ed.gov/programs/coe/indicator_cpa.asp.
} 
that state's economy. Strathman (1994) suggests that out-migration has a negative impact on a state's support for higher education.

However reasonable these arguments may sound, they cannot completely eliminate the possibility that institution-level state appropriations are endogenous. This is because the allocation of state appropriations across public institutions within states is unlikely to be random. Some unobserved, time-varying characteristics of an institution might influence both that institution's research productivity and how much funding that institution receives from the state. The direction of the related bias could go either way in theory and should be examined empirically.

To address the potential endogeneity problem, this paper runs two sets of IV regressions. In the first set, it uses a Bartik-type IV constructed by Deming and Walters (2017):

$$
Z_{i, t}^{1}=\left[\frac{\left(R_{2}\right)_{i, 0}}{(T R)_{i, 0}}\right] \times\left[\frac{\left(R_{2}\right)_{s, t}}{(C P)_{s, t}}\right],(6)
$$

where $\left(R_{2}\right)_{i, 0}$ and $(T R)_{i, 0}$ measure state appropriations and total revenue for institution $i$ in base year 0 (in this case, year 1987, the first year that one of the main datasets is available), and $\left(R_{2}\right)_{s, t}$ and $(C P)_{s, t}$ measure total state appropriations for public higher education and the college-age (age 19-23) population in state $s$ where institution $i$ is located in year $t .^{12}$ The first multiplication term in equation (6) captures ex ante differences across institutions in their dependence on state appropriations. It is fixed and therefore shuts down endogenous changes in state appropriations for institution $i$ driven by institution $i$ 's responses. The second multiplication term in equation (6) captures the aggregate shock in state appropriations (relative to the college-age populations) in each year, which is largely outside the control of individual institutions. After this paper puts together the first and second terms, the validity of this IV is based on a plausible assumption that

${ }^{12}$ Data on total state appropriations in state $s$ are obtained from the State Higher Education Executive Officers Association's State Higher Education Finance Project at http://www.sheeo.org/projects/shef-\%E2\%80\%94-statehigher-education-finance. 
institutions that historically have had greater dependence on state appropriations are likely to be affected more by future state-level budget shock.

This paper constructs another Bartik-type IV for the second set of IV regressions. It is constructed as

$$
Z_{i, t}^{2}=\frac{\left[\frac{\left(R_{2}\right)_{i, 0}}{\left(R_{2}\right)_{s, 0}}\right] \times\left(R_{2}\right)_{s, t}}{\left[\frac{N_{i, 0}}{(C P)_{s, 0}}\right] \times(C P)_{s, t}} .(7)
$$

Here the numerator essentially predicts state appropriations for institution $i$ in year $t$ by distributing total state appropriations in state $s$ in year $t$ based on institution $i$ 's share in base year 0 . Similarly, the denominator predicts the enrollment for institution $i$ in year $t$ by distributing the total college-age population in state $s$ in year $t$ based on institution $i$ 's share in base year 0 .

To show how this second IV is similar to and different from the first, equation (7) can be rearranged into

$$
Z_{i, t}^{2}=\left\{\frac{\left[\frac{\left(R_{2}\right)_{i, 0}}{\left(R_{2}\right)_{s, 0}}\right]}{\left[\frac{N_{i, 0}}{(C P)_{s, 0}}\right]}\right\} \times\left[\frac{\left(R_{2}\right)_{s, t}}{(C P)_{s, t}}\right] .
$$

The two IVs have in common the second multiplication term, which captures the same aggregate shock in state appropriations, while they hold different ex ante shares constant (that is, the first multiplication term).

\section{Data}

This paper relies mainly on two data sources. The first is the 1987-2012 Delta Cost Project (DCP) Database released by the NCES. This is a longitudinal dataset that integrates institution-level data from multiple Integrated Postsecondary Education Data System (IPEDS) surveys. It includes rich information on U.S. colleges and universities, including institution characteristics, funding 
sources, and expenditure categories. ${ }^{13}$ This paper limits the DCP data sample to public research universities, because other types of public institutions are much less likely to engage in highquality research activities that result in granted patents. So that it has a balanced panel, this paper keeps only those institutions that appear in the DCP database throughout the entire data period.

The second data source is a recent USPTO report titled "U.S. Colleges and Universities Utility Patent Grants, Calendar Years 1969-2012.” A utility patent is also called a "patent for invention," which is "issued for the invention of a new and useful process, machine, manufacture, or composition of matter, or a new and useful improvement thereof." ${ }^{\text {14 }}$ Utility patents are the most common type of patents, accounting for about 90 percent of the patents issued by the USPTO. The other, less common types of patents include design patents, plant patents, reissue patents, defensive publication, and statutory invention registration.

Due to the significant time delay between the filing for a patent and the issuing of that patent, many applications filed in 2004 and after were still pending when the USPTO published the report. Therefore, to avoid undercounting patent applications for these later years, this paper limits the sample period of the patent data to the years through 2003, for which the USPTO has cleared all applications.

The USPTO report assigns a patent to a U.S. college or university only if the institution is listed as the first-named assignee on the issued patent. It excludes any patents for which the firstnamed assignee is not a college or university or is a non-U.S. college or university, even if a U.S. college or university is listed as a secondary assignee. By doing so, the USPTO avoids doublecounting patents of U.S. colleges and universities at the aggregate level; however, it inevitably

\footnotetext{
${ }^{13}$ See https://nces.ed.gov/ipeds/deltacostproject/ for more details about the DCP data.

${ }^{14}$ See https://www.uspto.gov/web/offices/ac/ido/oeip/taf/patdesc.htm.
} 
undercounts patents of individual U.S. colleges and universities that are not the first-named assignees.

This paper specifically uses a data table in the USPTO report that lists the number of patents granted to the top-250 R\&D universities in the United States. ${ }^{15}$ The USPTO's list of the top-250 R\&D universities is based on an NSF ranking of R\&D expenditures of U.S. colleges and universities in fiscal year 2011 (NSF 2013). Some universities in the NSF ranking are specific campuses of state university systems, such as the University of California, San Diego, which is No. 6 in the NSF ranking. However, the USPTO is unable to identify every patent associated with each university campus, because some patent applications do not list a specific campus (for example, the University of California, San Diego); instead, they list the state university system (for example, the University of California) as the assignee on a patent. In such cases, the USPTO aggregates the patent count to a higher level, or a "consolidated institution," to ensure data consistency and accuracy.

The USPTO uses a crosswalk table to link each top-250 R\&D university in the NSF ranking to a USPTO-designated consolidated institution. ${ }^{16}$ In most cases, the consolidated institution is the same as the institution named in the NSF ranking. In other cases, the consolidated institution is a state university system. For example, the University of California, San Diego, is listed as a component of the University of California consolidated institution in the crosswalk table.

Using this crosswalk, this paper aggregates the DCP data to the level of consolidated institutions and then merges them with the patent data of the top- $250 \mathrm{R} \& \mathrm{D}$ institutions by the consolidated institution name. This process results in a final sample of 103 public institutions, including 11 consolidated institutions that are constructed by following the USPTO crosswalk and

\footnotetext{
${ }^{15}$ See https://www.uspto.gov/web/offices/ac/ido/oeip/taf/univ/org_fix/t250_univ_afx.htm.

${ }^{16}$ See https://www.uspto.gov/web/offices/ac/ido/oeip/taf/univ/r_and_d/r_d_nsf_2012.htm.
} 
aggregating multiple institutions that were previously listed separately. The final sample spans the 17-year period of 1987-2003, because the DCP data start in 1987 and the complete USPTO patent data end in 2003.

Figure 2 shows a scatterplot of state appropriations versus approved patent applications among these 103 public institutions over the 1987-2003 period. The upward-sloping line represents fitted values from a univariate regression of approved patent applications on state appropriations. It suggests that the number of approved patent applications is positively associated with the amount of state appropriations.

\section{Results}

This section uses fixed-effects panel data regressions to more rigorously examine the relationship between state appropriations and granted patents. Furthermore, it investigates whether heterogeneity and dynamics of the effect exist, and it identifies the underlying work mechanisms through which state appropriations affect the number of approved patent applications.

\section{Main Results}

The top panel of Table 1 shows the non-IV results from equation (5) and various robustness checks. This panel uses the Newey-West standard error estimator, which is robust to both heteroscedasticity and structured auto correlation of the error term. ${ }^{17}$ The maximum lag order of autocorrelation is set at 3 .

In the first column of Panel A (that is, the baseline specification), the estimated coefficient on state appropriations is positive and significant at the 5 percent level. An increase of $\$ 1,000$ in state appropriations per FTE student increases the number of approved patent applications by about

\footnotetext{
${ }^{17}$ I also tried clustering standard errors at the institution or state level for the non-IV regressions. Doing so increased estimated standard errors and rendered most of the non-IV results statistically insignificant. In comparison, the IV results in Panels B and C are mostly robust to clustering standard errors at the institution or state level.
} 
0.02 per 1,000 FTE students, on average. In other words, an increase of $\$ 42$ million in state appropriations results, on average, in approximately one additional approved patent application.

Column 2 adds the state unemployment rate to the baseline specification to control for state-specific time-varying economic conditions. One could argue that the state economy may influence the demand for patent research (even though the patent markets are more likely to be national or international) and at the same time affect state revenues and thereby state appropriations for public universities. Including the state unemployment rate has, however, virtually no impact on the coefficient on state appropriations.

Column 3 adds state-specific linear time trends to the baseline specification. The baseline result could suffer an omitted variable bias if it were driven by the time trends that are correlated with state appropriations. After I include state-specific time trends, the coefficient on state appropriations is still positive but somewhat smaller and less precisely estimated relative to the ones in Columns 1 and 2. This is likely because time trends absorb a large amount of variation, leaving less in use for identification. ${ }^{18}$

Column 4 drops net tuition and fees from the baseline specification. The concern is that net tuition and fees may be endogenous of state appropriations, because public universities may raise tuition and fees to partially offset state funding cuts, although the literature estimates that the effect of state appropriations on tuition and fees is relatively small (Koshal and Koshal 2000, Lowry 2001, NCES 2001, Rizzo and Ehrenberg 2004, Kim and Ko 2015, Goodman and Henriques 2015, and Webber 2017). ${ }^{19}$ Dropping net tuition and fees enables the coefficient on state appropriations

\footnotetext{
${ }^{18}$ I also tried adding institution-specific linear time trends to the baseline specification. Then the estimated coefficient on state appropriations became not significant. Future research may require a larger dataset with a longer sample period to accommodate institution-specific time trends that must absorb a substantial amount of variation.

${ }^{19}$ Based on a brief literature review, Delisle (2017) concludes that for every $\$ 1$ decrease in state appropriations, tuition and fees at public universities increase by $\$ 0.06$ to $\$ 0.10$. There are several possible explanations for the relatively small magnitude. First, the governing structure of the public higher education system in many states restricts public universities' ability to raise tuition and fees. A 2010-2011 survey by the State Higher Education Executive Officers
} 
to capture not only the direct effect of state appropriations on the number of approved patent applications, but also the indirect effect of state appropriations through their negative impact on net tuition and fees. Therefore, the coefficient on state appropriations in this specification is expected to be smaller than the one in the baseline specification. Indeed, the result in Column 4 is slightly smaller, but it remains positive and significant.

Column 5 drops potential outliers that might drive the results. The Georgia Institute of Technology and the University of California stand out in terms of patent research productivity. They own the 16 highest numbers of approved patent applications per 1,000 FTE students in the sample. After I drop these two institutions, the coefficient on state appropriations becomes somewhat smaller but still significant.

Columns 6 and 7 examine the extent to which the results are affected by potential bias caused by data aggregation. Column 6 drops 11 consolidated institutions, only the ones that this paper constructed by aggregating multiple institutions originally listed as separate units in the DCP database in order to match the USPTO's top-250 R\&D universities' patent data. The new coefficient on state appropriations is somewhat larger than the one in Column 1 and is highly significant. ${ }^{20}$

Column 7 drops 44 institutions, including the above 11 consolidated institutions and 33 other institutions flagged by the DCP because each represents a group of institutions. The DCP grouping occurs when some institutions (called parent institutions) report data not only for

\footnotetext{
Association indicates that the state legislature or the statewide coordinating governing agency has the primary tuitionsetting authority in 14 states, and the coordinating/governing boards for institutional systems have the primary tuitionsetting authority in 19 states (Bell, Carnahan, and L'Orange 2011). State legislatures and the centralized governing boards/agencies have a political incentive to maintain lower tuition and fees than desired by individual public institutions. Second, public universities' ability to raise tuition and fees is further restricted by states' often ad hoc tuition freezes and caps (Kim and Ko 2015, Povich 2015, Murray 2017). Third, public universities may not want to raise tuition and fees too high in order to stay price-competitive in the market (Povich 2015).

${ }^{20}$ The coefficient is significant at the 10 percent level, even when standard errors are clustered at the institution or state level.
} 
themselves, but also for branch campuses or other affiliated institutions (called child institutions) in some IPEDS surveys in some years. To ensure data consistency over time, the DCP groups the data of the involved parent and child institutions for all years in the sample. Jaquette and Parra (2016) argue that the DCP grouping approach introduces errors and might cause bias in empirical analysis. However, the authors recognize that "the extent to which DCP parent-child reporting affects empirical results will differ for each research question and cannot be predicted a priori” (p. 643). Using specific examples, they show that including institution fixed effects in the models can significantly mitigate the problem. Since the DCP grouping is constant for individual institutions during the sample period, any of its potential impact is largely, if not entirely, absorbed by institution fixed effects. Other studies, including the one by Deming and Walters (2017), find that using the DCP data produces empirical results similar to those produced using the raw IPEDS data without the DCP grouping. Nonetheless, after Column 7 drops the total 44 grouped institutions, the coefficient on state appropriations is qualitatively similar to the baseline result and remains highly significant. ${ }^{21}$

Columns 8 and 9 examine whether the use of the same denominator by the dependent variable and the explanatory variable of interest drives the results. Because, in previous columns, the number of approved patent applications and state appropriations both are scaled by the number of current-year FTE students, using the same denominator might mechanically create a positive relationship between the two variables on either side of the equation. In a hypothetical scenario where both numerators (that is, the number of approved patent applications and state appropriations) do not change, a change in the denominator (that is, the number of current-year FTE students) could drive the dependent variable and the explanatory variable of interest to move

\footnotetext{
${ }^{21}$ It is still significant at the 10 percent level if standard errors are clustered at the institution or state level.
} 
in the same direction. ${ }^{22}$ To break the mechanical link, Column 8 divides the number of approved patent applications by each institution's average number of FTE students in 1987-2003, a number that does not vary from one year to the next. This change barely affects the estimated coefficient on state appropriations relative to Column 1. Alternatively, Column 9 divides the number of approved patent applications by the number of current-year full-time faculty. The number of fulltime faculty does not change in perfect sync with the number of FTE students due in part to faculty tenure and contract constraints. Despite this change, the coefficient on state appropriations is still positive and significant.

The middle panel of Table 1 shows the first set of the IV results using the IV from Deming and Walters (2017), $Z_{i, t}^{1} \cdot{ }^{23}$ This IV proves to be a strong, significant predictor of institution-level state appropriations in all of the first-stage regressions. ${ }^{24}$ It also appears that applying the IV helps to correct the estimation bias and reduce data noises and improve the estimation precision. Thus, the regressions in this panel cluster standard errors at the state level, which allows for arbitrary correlations not only over time within institutions, but also between institutions within states. ${ }^{25}$

Panel B examines the same specifications and robustness checks as Panel A does. The IV results are generally robust. State appropriations are positive and significant at the 1 or 5 percent level in all but two cases. First, state appropriations turn negative and insignificant when Column

\footnotetext{
${ }^{22}$ It should be noted that if a state keeps the real value of total state appropriations constant despite the growth of student enrollment, it is, in fact and widely acknowledged, cutting funds on a per-student basis.

${ }^{23}$ The regressions in the middle panel use a sample period of 1988-2003; year 1987 is dropped because it is used as the base year in the IV. I also tried dropping more early years from the IV regressions, such as the first three years (1987-1989) or the first five years (1987-1991), so that the IV constructed based on the 1987 share could be even more exogenous (or predetermined) relative to state appropriations in later years. It turned out that the results were fairly similar regardless of the starting year of the regression sample period.

${ }^{24}$ For example, the coefficient on the IV in the first-stage regression of state appropriations for Column 1 (baseline specification) is 2.571 and significant at the 1 percent level.

${ }^{25}$ I also tried clustering standard errors at the institution level. The resulting standard errors and p-values are similar to the ones produced when standard errors were clustered at the state level.
} 
3 includes state-specific linear time trends. ${ }^{26}$ Because the IV construction is based partly on total state appropriations, which could have their own time trends, adding state-specific time trends might reduce the ability of the IV to generate exogenous variation to identify the coefficient. Second, state appropriations are also not significant when Column 7 drops the 44 grouped institutions. While the point estimate is still positive and on par with those in previous columns, it loses precision, likely due to the large reduction in the sample size. ${ }^{27}$

In terms of magnitude, the IV results in Panel B are generally larger than the non-IV results in Panel A. In six out of nine cases, the IV results are close to or more than double the non-IV results. This suggests that the potential endogeneity likely creates net downward bias. One reason could be that states believe public institutions with higher research productivity are more capable of generating their own revenues-such as through licensing patents, creating start-ups and spinoffs, and securing federal and private grants-and therefore provide lower state appropriations for these institutions than for public institutions with lower research productivity, while everything else is held equal. Based on the baseline result in Panel B (Column 1), an increase of \$19 million in state appropriations results, on average, in approximately one additional approved patent application.

\footnotetext{
${ }^{26}$ I also tried adding institution-specific linear time trends to the baseline specification when using the IV of Deming and Walters (2017). Then the estimated coefficient on state appropriations was positive, but close to 0 and insignificant.

${ }^{27}$ The coefficient would be significant at the 10 percent level if I used regular or heteroscedasticity-robust standard errors.
} 
The bottom panel of Table 1 shows the second set of the IV results when using $Z_{i, t}^{2}$ as the IV and clustering standard errors by state. ${ }^{28}$ Similar to $Z_{i, t}^{1}, Z_{i, t}^{2}$ proves to be a strong, significant predictor of institution-level state appropriations in all of the first-stage regressions. ${ }^{29}$

Panel C's IV results share a similar pattern with Panel B's IV results. First, state appropriations are always significant except for the scenarios in Column 3 (when state-specific linear time trends are added) and Column 7 (when the 44 grouped institutions are dropped). ${ }^{30}$ Second, the IV results in Panel C are generally greater than the non-IV results in Panel A. They are even greater than the IV results in Panel B. Based on the baseline result in Panel C (Column 1), an increase of $\$ 13$ million in state appropriations results, on average, in approximately one additional approved patent application.

In summary, an increase of $\$ 13$ million to $\$ 42$ million in state appropriations may result, on average, in one additional approved patent application from public research institutions, depending on whether an IV is used and which one is used. As a comparison, Payne and Siow (2003) find that a $\$ 5$ million increase in federal earmarked research funding leads to one more university patent. The reason that state appropriations have a smaller effect than federal earmarked research funding on university patent production is likely because state appropriations are generalpurpose revenues supporting all school spending, not just research expenditures, while federal earmarked research funding is, by definition, used mostly for research.

\section{Heterogeneous Effects}

\footnotetext{
${ }^{28}$ It uses the same sample period of 1988-2003 as Panel B. I also tried dropping additional early years from the IV regressions such as 1987-1989 or 1987-1991. The results are rarely affected by the starting year of the sample period.

${ }^{29}$ For example, the coefficient on $Z_{i, t}^{2}$ in the first-stage regression of state appropriations for Column 1 (baseline specification) is 0.366 and significant at the 1 percent level.

${ }^{30}$ The coefficient in Column 7 would be significant at the 5 percent level if I used regular or heteroscedasticity-robust standard errors.
} 
Different types of public research institutions may have different abilities to cope with state funding cuts, which therefore affect their research productivity to varying extents. For example, if institutions have to cut employee salaries to address state funding shortages, institutions with a higher level of research activity may experience a smaller decline in the quality of research faculty and staff than institutions with a lower level of research activity. This is because researchers may place a high value on the experience of working at a prestigious and high-quality lab or school and thus would be willing to accept the lower pay offered by institutions with high levels of research activity. Thus, compared with institutions with a lower level of research activity, institutions with a higher level of research activity may be less likely to experience a negative impact from state appropriation cuts, or they may experience a smaller negative impact.

This paper uses a split-sample regression method to test this hypothesis. I divide the full sample into two subsamples, one that includes institutions with a relatively high level of research activity and another that includes institutions with a relatively low level of research activity. The level of research activity is approximated by the 2000 Carnegie Classification of Institutions of Higher Learning. Using the degree-granting activities of colleges and universities from 1996 through 1998, this classification separates doctoral/research universities into two mutually exclusive and exhaustive categories: "extensive" and "intensive." Extensive research universities are defined as schools that awarded 50 or more doctoral degrees per year across at least 15 disciplines. Intensive research universities are defined as schools that awarded at least 10 doctoral degrees per year across three or more disciplines, or at least 20 doctoral degrees per year overall. Extensive research universities are generally regarded as having a higher level of research activity compared with intensive research universities. 
I run the same baseline specification on each subsample separately. Doing so allows the coefficients on state appropriations and on other common variables to differ across subsamples. I also run non-IV and IV regressions. Standard errors in the non-IV regressions are estimated using the Newey-West standard error estimator with the maximum lag order of autocorrelation set at 3. Standard errors in the IV regressions are clustered at the institution level, not at the state level, to ensure a sufficient number of clusters in each subsample, because not every state has at least one institution in each subsample.

In Columns 1 (non-IV results) and 2 (using $Z_{i, t}^{1}$ as the IV) of Table 2, state appropriations are significant only for institutions with a relatively low level of research activity. In Column 3 (using $Z_{i, t}^{2}$ as the IV), state appropriations are more significant for institutions with a relatively low level of research activity than they are for institutions with a relatively high level of research activity. Furthermore, in all three columns, the coefficient for institutions with a relatively low level of research activity is greater than the coefficient for institutions with a relatively high level of research activity. However, the two coefficients in each column are not statistically significantly different from each other. Overall, there is only weak evidence that the effect of state appropriations on the number of approved patent applications differs according to the level of research activity of public institutions.

\section{Lag Effects}

Public institutions' research activities may be affected by previous years' state appropriations as well as the current year's state appropriations. When state appropriations increase, it may take time for universities to build new research facilities, upgrade lab equipment, and hire more research faculty and staff. Conversely, when state appropriations decrease, universities may make gradual downward adjustments in research faculty and staff, equipment, and facilities over several years. 
To test this hypothesis, the regressions in Table 3 add the four previous years' state appropriations to the baseline specification. However, two data challenges limit the ability of the new regressions to identify the coefficients on these lag terms. First, the sample size significantly diminishes, because the first four years' patent data have to be dropped in order to accommodate the four lagged values of state appropriations on the right-hand side of the estimation equation. A smaller sample inevitably reduces the testing power. Second, the variable of state appropriations has high serial correlation. The correlation among state appropriations per FTE student in years $t, t-1, t-2, t-3$, and $t-4$ ranges from 0.90 to 0.97 .

Table 3 shows three patterns of the results. First, the current year's state appropriations remain positive and significant across non-IV and IV regressions. Second, while none of the previous years' state appropriations are significant in the non-IV regressions, state appropriations from three years earlier are positive and significant in both IV regressions, which suggests that state appropriations may indeed have a lag effect on the number of approved patent applications. Third, the accumulative effect of state appropriations over a five-year period, which is calculated by summing the coefficients on state appropriations from year $t-4$ to year $t$, is fairly close to the contemporaneous effect of state appropriations in Column 1 of Table 1.

\section{Underlying Work Mechanisms}

The school budget constraint and the research-production function (that is, equations 2 and 3 ) jointly suggest that research expenditures could be a main channel through which state appropriations affect the number of approved patent applications from public research institutions. ${ }^{31}$ Whalley and Hicks (2014) show that research expenditures have a substantial

\footnotetext{
${ }^{31}$ I also examined the impact of state appropriations on other measures of research inputs, such as the number of fulltime faculty per FTE student and the number of graduate students per FTE student. However, none of the results were significant in the IV regressions.
} 
positive impact on universities' research output as measured by the number of papers published. However, Lowry (2001) shows that budgeted research spending of public universities is not significantly associated with state government funding. Because that paper is based on a crosssectional regression and uses data from only one year (1994-1995), its results could suffer a bias from not controlling for unobserved heterogeneity among universities. In particular, its sample of 428 public four-year universities includes both research universities and non-research universities that spend only minimally on research.

To improve on Lowry (2001), this paper uses a panel data model with institution and year fixed effects to examine the extent to which state appropriations affect the research expenditures of public research institutions. It essentially estimates the school budget constraint (that is, equation 2) using the following reduced-form specification:

$$
\left(\frac{E_{2}}{N}\right)_{i t}=\alpha+\beta_{1}\left(\frac{R_{1}}{N}\right)_{i t}+\beta_{2}\left(\frac{R_{2}}{N}\right)_{i t}+\beta_{3}\left(\frac{R_{3}}{N}\right)_{i t}+I_{i}+T_{t}+v_{i t .} \text { (8) }
$$

It runs non-IV and IV regressions. It also tries an alternative specification in which net tuition and fees $\left(\frac{R_{1}}{N}\right)_{i t}$ are dropped because they may be endogenous of state funding. However, the results are almost the same as those when net tuition and fees are included in the regressions. Therefore, Table 4 shows only the results from the regressions that include net tuition and fees.

This paper uses two measures of research expenditures: total research expenditures and research expenditures on salaries and wages. Salaries and wages paid to researchers are important because they account for more than half of the total research expenditures across public institutions in the sample.

Contrary to Lowry (2001), Table 4 shows that state appropriations have a positive, significant impact on how much money public research institutions spend on research activities and salaries and wages paid to research staff. Depending on whether an IV is used and which one 
is used, a $\$ 1$ increase in state appropriations results, on average, in an increase of $\$ 0.15$ to $\$ 0.21$ in total research expenditures and of $\$ 0.11$ to $\$ 0.15$ in research expenditures on salaries and wages. Thus, the impact of state appropriations on research expenditures is concentrated on salaries and wages paid to researchers.

\section{Conclusion}

This paper finds that state appropriations have a positive effect on the number of approved patent applications from public research institutions. State appropriations impact public institutions' patent production through the schools' research expenditures, especially research expenditures on salaries and wages. These results suggest that state disinvestment in higher education, which has occurred over the past several decades, reduces the research productivity of public institutions and has broader negative implications beyond the classroom. 


\section{References}

Adams, James D. 2002. "Comparative Localization of Academic and Industrial Spillovers.” Journal of Economic Geography 2(3): 253-278.

Anselin, Luc, Attila Varga, and Zoltan Acs. 1997. "Local Geographic Spillovers between University Research and High Technology Innovations." Journal of Urban Economics 42(3): 422-448.

Arora, Ashish, and Alfonso Gambardella. 2005. "The Impact of NSF Support for Basic Research in Economics." Annales d'Economie et de Statistique 79: 91-117.

Bania, Neil, Randall W. Eberts, and Michael S. Fogarty. 1993. "Universities and the Startup of New Companies: Can We Generalize from Route 128 and Silicon Valley?" The Review of Economics and Statistics 75(4): 761-766.

Bell, Allison C., Julie Carnahan, and Hans P. L'Orange. 2011. State Tuition, Fees, and Financial Assistance Policies for Public Colleges and Universities, 2010-11. Boulder, CO: State Higher Education Executive Officers Association.

Castellanos, Sara. 2015. "UMass Awarded a Record Number of Patents this Year." Boston Business Journal. August 18.

Conroy, Kevin, and Tom Shannon. 2015. "Cuts to UW System Could Seriously Hurt State's Economic Growth.” Milwaukee Journal Sentinel. February 13.

Delisle, Jason. 2017. The Disinvestment Hypothesis: Don't Blame State Budget Cuts for Rising Tuition at Public Universities. Washington, DC: Brookings Institution.

Deming, David J., and Christopher R. Walters. 2017. "The Impact of Price Caps and Spending Cuts on U.S. Postsecondary Attainment." Working Paper 23736. Cambridge, MA: National Bureau of Economic Research.

Ehrenberg, Ronald G. 2000. Tuition Rising: Why College Costs So Much. Cambridge, MA: Harvard University Press.

Ehrenberg, Ronald G., and Daniel R. Sherman. 1984. "Optimal Financial Aid Policies for a Selective University.” Journal of Human Resources 19(2): 202-230.

Garvin, David A. 1980. The Economics of University Behavior. New York, NY: The Academic Press.

Goodman, Sarena F., and Alice M. Henriques. 2015. "Attendance Spillovers between Public and For-Profit Colleges: Evidence from Statewide Changes in Appropriations for Higher Education." Finance and Economics Discussion Series 2015-025. Washington, DC: Board of Governors of the Federal Reserve System. 
Groot, Hans de, Walter W. McMahon, and J. Fredericks Volkwein. 1991. "The Cost Structure of American Research Universities." The Review of Economics and Statistics 73(3): 424-431.

Gush, Jason, Adam B. Jaffe, Victoria Larsen, and Athene Laws. 2017. "The Effect of Public Funding on Research Output: The New Zealand Marsden Fund." New Zealand Economic Papers.

Husted, Thomas A., and Lawrence W. Kenny. 2015. "The Effect of Reduced Support from State Government on Research in State Universities." Paper presented at the Southern Economic Association Annual Conference.

Jacob, Brian A., and Lars Lefgren. 2011a. "The Impact of Research Grant Funding on Scientific Productivity." Journal of Public Economics 95(9): 1168-1177.

Jacob, Brian A., and Lars Lefgren. 2011b. "The Impact of NIH Postdoctoral Training Grants on Scientific Productivity." Research Policy 40(6): 864-874.

Jaffe, Adam B. 1989. "Real Effects of Academic Research.” American Economic Review 79(5): 957-970.

Jaquette, Ozan, and Bradley Curs. 2015. "Creating the Out-of-State University: Do Public Universities Increase Nonresident Freshman Enrollment in Response to Declining State Appropriations?" Research in Higher Education 56(6): 535-565.

Jaquette, Ozan, and Edna Parra. 2016. "The Problem with the Delta Cost Project Database." Research in Higher Education 57(5): 630-651.

Kane, Thomas J., Peter R. Orszag, and Emil Apostolov. 2005. "Higher Education Appropriations and Public Universities: Role of Medicaid and the Business Cycle [with comments]." BrookingsWharton Papers on Urban Affairs: 99-146.

Kane, Thomas J., Peter R. Orszag, and David L. Gunter. 2003. "State Fiscal Constraints and Higher Education Spending: The Role of Medicaid and the Business Cycle." Urban-Brookings Tax Policy Center Discussion Paper No.11.

Kim, Mikyong Minsun, and Jangwan Ko. 2015. "The Impacts of State Control Policies on College Tuition Increase.” Educational Policy 29(5): 815-838.

Koshal, Rajindar K., and Manjulika Koshal. 2000. "State Appropriation and Higher Education Tuition: What Is the Relationship?" Education Economics 8(1): 81-89.

Long, Bridget Terry. 2016. State Support for Higher Education: How Changing the Distribution of Funds Could Improve College Completions Rates. Charlottesville, VA: National Commission on Financing 21st Century Higher Education.

Lowry, Robert C. 2001. "The Effects of State Political Interests and Campus Outputs on Public University Revenues.” Economics of Education Review 20(2): 105-119. 
Mansfield, Edwin. 1995. "Academic Research Underlying Industrial Innovations: Sources, Characteristics, and Financing." The Review of Economics and Statistics 77(1): 55-65

Mansfield, Edwin, and Jeong-Yeon Lee. 1996. "The Modern University: Contributor to Industrial Innovation and Recipient of Industrial R\&D Support.” Research Policy 25(7): 1047-1058.

Mitchell, Michael, and Michael Leachman. 2015. Years of Cuts Threaten to Put College Out of Reach for More Students. Washington, DC: Center on Budget and Policy Priorities.

Mitchell, Michael, Michael Leachman and Kathleen Masterson. 2016. Funding Down, Tuition Up: State Cuts to Higher Education Threaten Quality and Affordability at Public Colleges. Washington, DC: Center on Budget and Policy Priorities.

Murray, Stephanie. 2017. "UMASS Tuition/Fees Likely to Increase by 2 to 3 Percent, Meehan Says." State House News Service. June 20.

National Association of State Budget Officers (NASBO). 2015. State Expenditure Report: Examining Fiscal 2013-2015 State Spending. Washington, DC: National Association of State Budget Officers.

National Center for Education Statistics (NCES). 2001. Study of College Costs and Prices, 198889 to 1997-98. Washington, DC: NCES.

National Conference of State Legislatures (NCSL). 2015. Performance-Based Funding for Higher Education. Washington, DC: National Conference of State Legislatures.

National Science Foundation (NSF). 2013. Higher Education Research and Development: Fiscal Year 2011. Washington DC: NSF.

Okunade, Albert A. 2004. "What Factors Influence State Appropriations for Public Higher Education in the United States?” Journal of Education Finance 30(2): 123-138.

Payne, A. Abigail. 2002. "Do US Congressional Earmarks Increase Research Output at Universities?" Science and Public Policy 29(5): 314-330.

Payne, A. Abigail, and Aloysius Siow. 2003. "Does Federal Research Funding Increase University Research Output?” Advances in Economic Analysis \& Policy 3(1): 1-24.

Popp, David. 2016. "Economic Analysis of Scientific Publications and Implications for Energy Research and Development." Nature Energy 1(4): 1-8.

Povich, Elaine S. 2015. “To Balance Budgets, Governors Seek Higher Education Cuts.” Stateline. March 27. 
Rizzo, Michael, and Ronald G. Ehrenberg. 2004. "Resident and Nonresident Tuition and Enrollment at Flagship State Universities," in ed., Caroline M. Hoxby, College Choices: The Economics of Where to Go, When to Go, and How to Pay For It. Chicago, IL: University of Chicago Press. 303-353.

Serna, Gabriel R., and Gretchen Harris. 2014. "Higher Education Expenditures and State Budget Requirements: Is There a Relationship?" Journal of Education Finance 39(3): 175-202.

Snell, Ronald K. 2011. State Experiences with Annual and Biennial Budgeting. Washington, DC: National Conference of State Legislatures.

Strathman, James G. 1994. "Migration, Benefit Spillovers and State Support of Higher Education." Urban Studies 31(6): 913-920.

Tandberg, David A. 2010. "Politics, Interest Groups and State Funding of Public Higher Education." Research in Higher Education 51(5): 416-450.

Webber, Douglas A. 2017. "State Disinvestment and Tuition at Public Institutions." Economics of Education Review 60: 1-4.

Weerts, David J., and Justin M. Ronca. 2006. "Examining Differences in State Support for Higher Education: A Comparative Study of State Appropriations for Research I Universities." Journal of Higher Education 77(6): 935-967.

Whalley, Alexander, and Justin Hicks. 2014. "Spending Wisely? How Resources Affect Knowledge Production in Universities.” Economic Inquiry 52(1): 35-55.

Zhang, Liang. 2009. "Does State Funding Affect Graduation Rates at Public Four-Year Colleges and Universities?" Educational Policy 23(5): 714-731.

Zheng, Ping, and Timothy F. Slaper. 2016. "University Knowledge Spillovers, Geographic Proximity and Innovation: An Analysis of Patent Filings across U.S. Counties.” Indiana University Kelley School of Business Research Paper No. 16-76. 
Figure 1. State Appropriations as a Share of Total Revenues of Public Degree-Granting Postsecondary Institutions in the United States

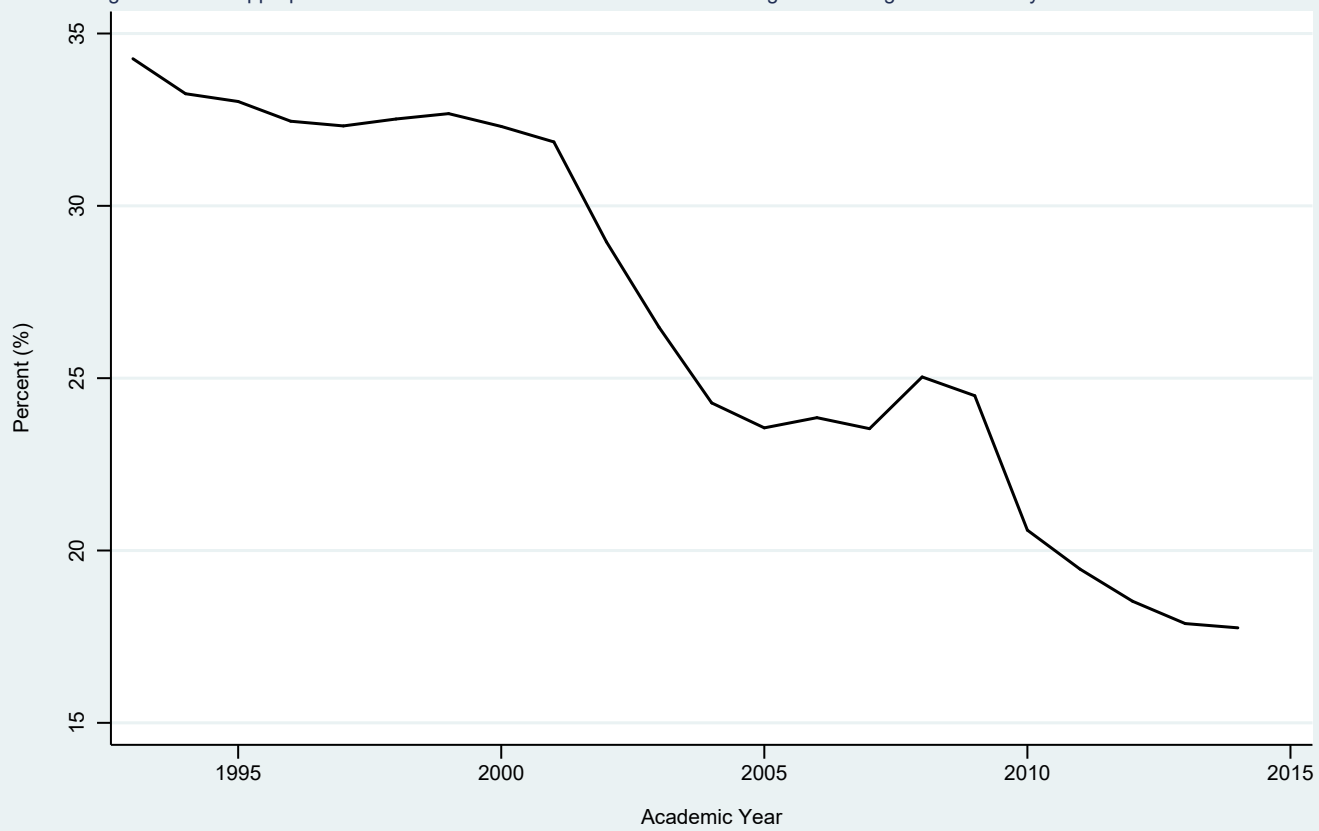

Source: National Center for Education Statistics, Digest of Education Statistics.

Note: Total revenues for 2002 and 2003 and state appropriations for 2002 are missing and are estimated using interpolation. 
Figure 2. State Appropriations versus Approved Patent Applications, 1987-2003

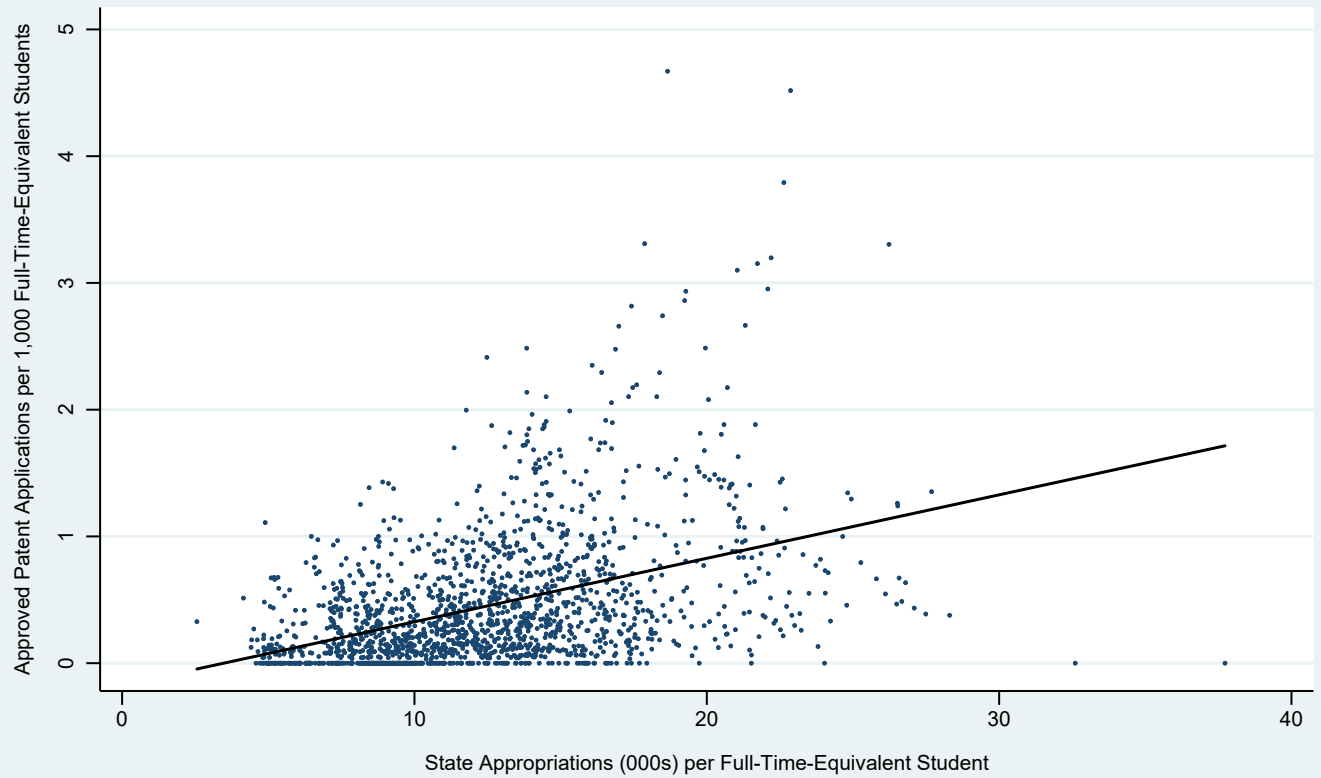

Source: Author's calculations.

Note: The figure is based on the data of 103 public research institutions for 1987-2003. The upward-sloping straight line is generated from a univariate regression of approved patent applications per 1,000 full-time-equivalent students on state appropriations (000s) per full-time-equivalent student. State appropriations are in 2012 dollars. 
Table 1. Estimating the Effect of State Appropriations on the Number of Approved Patent Applications from Public Research Institutions: Main Results

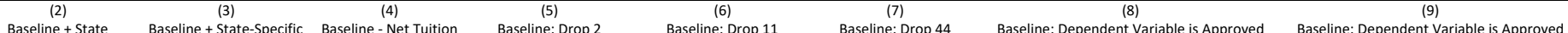

\begin{tabular}{|c|c|c|c|c|c|c|c|c|c|}
\hline & $\begin{array}{c}1) \\
\text { Baseline }\end{array}$ & $\begin{array}{c}\text { (2) } \\
\text { Baseline + State } \\
\text { Unemployment Rates }\end{array}$ & $\begin{array}{c}\text { (3) } \\
\text { Baseline + State-Specific } \\
\text { Linear Time Trends }\end{array}$ & $\begin{array}{c}(4) \\
\text { Baseline - Net Tuition } \\
\text { and Fees }\end{array}$ & $\begin{array}{c}\text { (5) } \\
\text { Baseline: Drop } 2 \\
\text { "Outlier" Institutions } \\
\end{array}$ & $\begin{array}{c}\text { (6) } \\
\text { Baseline: Drop } 11 \\
\text { Consolidated Institutions }\end{array}$ & $\begin{array}{c}\text { (7) } \\
\text { Baseline: Drop } 44 \\
\text { Grouped Institutions }\end{array}$ & $\begin{array}{l}\text { (8) } \\
\text { Baseline: Dependent Variable is Approved } \\
\text { Patent Applications/Average FTE Students }\end{array}$ & $\begin{array}{l}\text { (9) } \\
\text { Baseline: Dependent Variable is Approved } \\
\text { Patent Applications/ Full-Time Faculty }\end{array}$ \\
\hline \multicolumn{10}{|l|}{ A. Non-IV Results } \\
\hline State Appropriations per FTE Student & $\begin{array}{c}0.0236^{* *} \\
(0.0106)\end{array}$ & $\begin{array}{l}0.0234^{* *} \\
(0.0107)\end{array}$ & $\begin{array}{l}0.0173^{*} \\
(0.0105) \\
\end{array}$ & $\begin{array}{l}0.0207^{*} \\
(0.0106)\end{array}$ & $\begin{array}{l}0.0158^{* *} \\
(0.00681) \\
\end{array}$ & $\begin{array}{c}0.0353^{* * *} \\
(0.0107)\end{array}$ & $\begin{array}{c}0.0311^{* * *} \\
(0.0110)\end{array}$ & $\begin{array}{l}0.0233^{* *} \\
(0.0113)\end{array}$ & $\begin{array}{l}0.0382 * * \\
(0.0162)\end{array}$ \\
\hline \multicolumn{10}{|l|}{ B. IV results using $z_{i t}{ }^{1}$ as the IV } \\
\hline State Appropriations per FTE Student & $\begin{array}{c}0.0532^{* * *} \\
(0.0191)\end{array}$ & $\begin{array}{c}0.0556^{* * *} \\
(0.0207)\end{array}$ & $\begin{array}{r}-0.0170 \\
(0.0315) \\
\end{array}$ & $\begin{array}{l}0.0403^{* *} \\
(0.0179) \\
\end{array}$ & $\begin{array}{l}0.0482 * * \\
(0.0213)\end{array}$ & $\begin{array}{c}0.0518^{* * *} \\
(0.0198) \\
\end{array}$ & $\begin{array}{c}0.0421 \\
(0.0421)\end{array}$ & $\begin{array}{c}0.0585^{* * *} \\
(0.0196)\end{array}$ & $\begin{array}{c}0.0888^{* * *} \\
(0.0272) \\
\end{array}$ \\
\hline \multicolumn{10}{|l|}{ C. IV results using $z_{i t}^{2}$ as the IV } \\
\hline State Appropriations per FTE Student & $\begin{array}{c}0.0746^{* * *} \\
(0.0206) \\
\end{array}$ & $\begin{array}{c}0.0791^{* * *} \\
(0.0220) \\
\end{array}$ & $\begin{array}{l}0.00974 \\
(0.0221) \\
\end{array}$ & $\begin{array}{c}0.0658^{* * *} \\
(0.0203) \\
\end{array}$ & $\begin{array}{c}0.0618^{* * *} \\
(0.0239) \\
\end{array}$ & $\begin{array}{c}0.0798 * * * \\
(0.0230) \\
\end{array}$ & $\begin{array}{r}0.0542 \\
(0.0483) \\
\end{array}$ & $\begin{array}{c}0.0857 * * * \\
(0.0230) \\
\end{array}$ & $\begin{array}{c}0.107^{* * *} \\
(0.0293) \\
\end{array}$ \\
\hline
\end{tabular}

Source: Author's calculations.

Notes: (1) The sample includes 103 public research institutions unless otherwise indicated.
(2) The sample period for the non-IV regressions is $1987-2003$. The sample period for the IV regressions is $1988-2003$

(2) The sampe 5 equations 6 and 7 for the construction of the IVs, $Z^{1}$. The $z^{2}$ respectively.

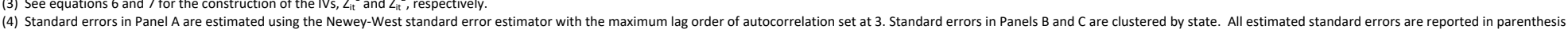

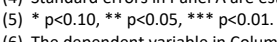

(6) The dependent variable in Columns $1-7$ is the number of approved patent applications per 1,000 FTE students

(7) The baseline specification includes controls for net tuition and fees per FTE student, federal grants and contracts per FTE student, private gifts, grants, and contracts per FTE student, federal appropriations per FTE student, investment return per FTE student, local appropriations per FTE student, total FTE

(8) All financial variables are in thousands of 2012 dollars.

(9) Column 5 excludes Georgia Institute of Technology and the University of California.

(10) Column 6 drops 11 consolidated histintions that his paper constructed each by aggregating multiple institutions originally listed as separate units in the DCP database. 
Table 2. Estimating State Appropriations' Effect by the Level of Public Institutions' Research Activity Coefficients on State Appropriations per FTE Student

\begin{tabular}{lccc}
\hline & \multicolumn{3}{c}{ Coefficients on State Appropriations per FTE Student } \\
\cline { 2 - 4 } & $\begin{array}{c}(1) \\
\text { Non-IV Results }\end{array}$ & $\begin{array}{c}(2) \\
\text { IV Results Using Z }{ }_{\text {it }}{ }^{2} \text { as the IV }\end{array}$ & IV Results Using Z ${ }^{2}{ }^{2}$ as the IV \\
\hline High Level of Research Activity & 0.0170 & 0.0263 & $0.0587^{*}$ \\
& $(0.0141)$ & $(0.0262)$ & $(0.0354)$ \\
Low Level of Research Activity & & & $0.0949^{* *}$ \\
& $0.0260^{*}$ & $0.0912^{* *}$ & $(0.0477)$ \\
\hline
\end{tabular}

Source: Author's calculations.

Notes: (1) The 2000 Carnegie Classification of Institutions of Higher Learning classifies doctoral/research universities into extensive research universities and intensive research universities, with the former generally regarded as having a higher level of research activity.

(2) The subsample for the high level of research activity includes 71 public institutions. The subsample for the low level of research activity includes 32 public institutions.

(3) The sample period for the non-IV regressions is 1987-2003. The sample period for the IV regressions is 1988-2003.

(4) See equations 6 and 7 for the construction of the IVs, $Z_{i t}{ }^{1}$ and $Z_{i t}{ }^{2}$, respectively.

(5) Standard errors in the non-IV regressions are estimated using the Newey-West standard error estimator with the maximum lag order of autocorrelation set at 3. Standard errors in the IV regressions are clustered by institution. All estimated standard errors are reported in parenthesis.

(6) $* \mathrm{p}<0.10, * * \mathrm{p}<0.05, * * * \mathrm{p}<0.01$.

(7) The dependent variable is the number of approved patent applications per 1,000 FTE students.

(8) The regressions use the baseline specification that includes controls for net tuition and fees per FTE student, federal grants and contracts per FTE student, private gifts, grants, and contracts per FTE student, federal appropriations per FTE student, investment return per FTE student, local appropriations per FTE student, total FTE students, institution and year fixed effects, as well as a constant.

(9) All financial variables are in thousands of 2012 dollars. 
Table 3. Exploring Lag Effects of State Appropriations on the Number of Approved Patent Applications

\begin{tabular}{|c|c|c|c|}
\hline & $\begin{array}{c}\text { (1) } \\
\text { Non-IV Results }\end{array}$ & $\begin{array}{c}\text { (2) } \\
\text { IV Results Using } Z_{\text {it }}{ }^{1} \text { as the IV }\end{array}$ & $\begin{array}{c}\text { (3) } \\
\text { IV Results Using } Z_{i t}{ }^{2} \text { as the IV }\end{array}$ \\
\hline \multirow[t]{2}{*}{ State Appropriations per FTE Student } & $0.0172 *$ & $0.0779 *$ & $0.115^{* * *}$ \\
\hline & $(0.00949)$ & $(0.0427)$ & $(0.0412)$ \\
\hline \multirow[t]{2}{*}{ State Appropriations per FTE Student, 1-Year Lag } & -0.0112 & -0.0470 & $-0.0690 * *$ \\
\hline & $(0.00817)$ & $(0.0287)$ & $(0.0299)$ \\
\hline \multirow[t]{2}{*}{ State Appropriations per FTE Student, 2-Year Lag } & 0.0146 & 0.00922 & 0.00593 \\
\hline & $(0.0124)$ & $(0.0156)$ & $(0.0152)$ \\
\hline \multirow[t]{2}{*}{ State Appropriations per FTE Student, 3-Year Lag } & 0.00658 & $0.0118^{* *}$ & $0.0150 * *$ \\
\hline & $(0.00679)$ & $(0.00576)$ & $(0.00646)$ \\
\hline \multirow[t]{2}{*}{ State Appropriations per FTE Student, 4-Year Lag } & 0.00253 & 0.00339 & 0.00392 \\
\hline & $(0.00637)$ & $(0.00632)$ & $(0.00650)$ \\
\hline Accumulative Effect of State Appropriations & 0.0297 & 0.0553 & 0.0712 \\
\hline
\end{tabular}

Source: Author's calculations.

Notes: (1) The sample includes 103 public research institutions.

(2) See equations 6 and 7 for the construction of the $I V s, Z_{i t}{ }^{1}$ and $Z_{i t}{ }^{2}$, respectively.

(3) Standard errors in the non-IV regressions are estimated using the Newey-West standard error estimator with the maximum lag order of autocorrelation set at 3. Standard errors in the IV regressions are clustered by state. All estimated standard errors are reported in parenthesis.

(4) $* \mathrm{p}<0.10, * * \mathrm{p}<0.05, * * * \mathrm{p}<0.01$.

(5) The dependent variable is the number of approved patent applications per 1,000 FTE students.

(6) The specifications include controls for net tuition and fees per FTE student, federal grants and contracts per FTE student, private gifts, grants, and contracts per FTE student, federal appropriations per FTE student, investment return per FTE student, local appropriations per FTE student, total FTE students, institution and year fixed effects, as well as a constant.

(7) All financial variables are in thousands of 2012 dollars.

(8) The accumulative effect of state appropriations is calculated by summing the coefficients on state appropriations from year t- 4 to year $t$. 
Table 4. Exploring the Channels through which State Appropriations Affect the Number of Approved Patent Applications

\begin{tabular}{lccc}
\hline & \multicolumn{3}{c}{ A. Dependent Variable = Research Expenditures per FTE Student } \\
\cline { 2 - 4 } & Non-IV Results & IV Results Using $Z_{\text {it }}{ }^{1}$ as the IV & IV Results Using $Z_{\text {it }}{ }^{2}$ as the IV \\
\hline State Appropriations per FTE Student & $0.150^{* * *}$ & $0.186^{* * *}$ & $0.214^{* * *}$ \\
& $(0.0210)$ & $(0.0646)$ & $(0.0724)$ \\
\hline
\end{tabular}

\begin{tabular}{lccc}
\hline & \multicolumn{3}{c}{ B. Dependent Variable = Research Expenditures on Wages and Salaries per FTE Student } \\
\cline { 2 - 4 } & Non-IV Results & IV Results Using $Z_{\text {it }}{ }^{1}$ as the IV & IV Results Using $Z_{\text {it }}{ }^{2}$ as the IV \\
\hline State Appropriations per FTE Student & $0.129^{* * *}$ & $0.154^{* * *}$ & $0.105^{* *}$ \\
& $(0.0314)$ & $(0.0461)$ & $(0.0504)$ \\
\hline
\end{tabular}

Source: Author's calculations.

Notes: (1) The sample includes 103 public research institutions.

(2) The sample period for the non-IV regressions is 1987-2003. The sample period for the IV regressions is 1988-2003.

(3) See equations 6 and 7 for the construction of the IVs, $Z_{i t}{ }^{1}$ and $Z_{i t}{ }^{2}$, respectively.

(4) Standard errors in the non-IV regressions are estimated using the Newey-West standard error estimator with the maximum lag order of autocorrelation set at 3 . Standard errors in the IV regressions are clustered by state. All estimated standard errors are reported in parenthesis.

$(5) * p<0.10, * * p<0.05, * * * p<0.01$.

(6) The specifications include controls for net tuition and fees per FTE student, federal grants and contracts per FTE student, private gifts, grants, and contracts per FTE student, federal appropriations per FTE student, investment return per FTE student, local appropriations per FTE student, institution and year fixed effects, as well as a constant.

(7) All financial variables are in thousands of 2012 dollars. 